\title{
Combination therapies augment the anti-tumor activity of agonist CD27 mAb in human CD27 transgenic mouse models
}

\author{
Li-Zhen He ${ }^{1}$, Lawrence J Thomas ${ }^{2}$, James Testa ${ }^{1}$, Jeffrey Weidlick' Crystal Sisson ${ }^{1}$, Russell Hammond², \\ Laura Vitale ${ }^{1}$, Henry Marsh'², Tibor Keler ${ }^{1 *}$ \\ From Society for Immunotherapy of Cancer 28th Annual Meeting \\ National Harbor, MD, USA. 8-10 November 2013
}

CDX-1127 is a fully human antibody to CD27, a TNF receptor superfamily member expressed on the majority of $\mathrm{T}$ cells and subsets of NK cells and B cells. We have previously characterized the co-stimulatory activities of CDX-1127 with human $T$ cell cultures and a human CD27 transgenic mouse model (hCD27-Tg). Similar to the findings originally shown by M.J. Glennie and colleagues using an agonist anti-mouse CD27 mAb, CDX1127 has potent antitumor activity as monotherapy in several syngeneic tumor models in hCD27-Tg mice. In the current studies, we sought to enhance the antitumor efficacy of CDX-1127 in challenging tumor settings by combination with clinically relevant therapies. Specifically, we focused on therapies that could decrease or control tumor growth while providing a source of antigen to drive anti-tumor immunity (e.g. chemotherapy or targeted therapy) and immune modifiers that may allow the CD27 driven $\mathrm{T}$ cell response to overcome self-regulation (e.g. checkpoint inhibitors or immune activators). In the EG7 delayed treatment model (average tumor size of $\sim 50 \mathrm{~mm} 3$ when treatment initiated), the combination of CDX-1127 with cyclophosphamide significantly improved survival ( $>70 \%$ survival) compared to either agent alone ( $<30 \%$ survival). Notably, we found that the combination therapy was associated with increases in the ratio of effector to regulatory $\mathrm{T}$ cells in the tumors compared to either single agent group. Additional combination studies with various agents are ongoing, and initial studies with CDX-1127 combined with anti-CTLA-4 mAb has shown superior anti-tumor activity (median survival 36.5 days in combination versus

'Celldex Therapeutics, Inc., Phillipsburg, NJ, USA

Full list of author information is available at the end of the article
20 days with either single agent). These studies, along with the good safety profile of CDX-1127 reported in a Phase 1 clinical trial, supports the design of future combination studies in patients with cancer.

\section{Authors' details}

${ }^{1}$ Celldex Therapeutics, Inc., Phillipsburg, NJ, USA. ${ }^{2}$ Celldex Therapeutics, Inc., Needham, NJ, USA.

Published: 7 November 2013

doi:10.1186/2051-1426-1-S1-P76

Cite this article as: He et al:: Combination therapies augment the antitumor activity of agonist $\mathrm{CD} 27 \mathrm{mAb}$ in human $\mathrm{CD} 27$ transgenic mouse models. Journal for ImmunoTherapy of Cancer 2013 1(Suppl 1):P76.
Submit your next manuscript to BioMed Central and take full advantage of:

- Convenient online submission

- Thorough peer review

- No space constraints or color figure charges

- Immediate publication on acceptance

- Inclusion in PubMed, CAS, Scopus and Google Scholar

- Research which is freely available for redistribution
C Biomed Central

\section{() BioMed Central}

(c) 2013 He et al; licensee BioMed Central Ltd. This is an Open Access article distributed under the terms of the Creative Commons Attribution License (http://creativecommons.org/licenses/by/2.0), which permits unrestricted use, distribution, and reproduction in any medium, provided the original work is properly cited. 